\title{
Exploring the consequences of teachers' self-efficacy: a case of teachers of English as a foreign language
}

\author{
Goudarz Alibakhshi ${ }^{{ }^{*}}$, Fariborz Nikdel ${ }^{2}$ and Akram Labbafi $^{3}$
}

\author{
*Correspondence: alibakhshi@atu. \\ ac.ir \\ ${ }^{1}$ Allameh Tabataba'i University, \\ Olympics dehkedeh, Varezesh \\ Street, Tehran, Iran \\ Full list of author information is \\ available at the end of the article
}

\begin{abstract}
Teacher self-efficacy has been abundantly studied. However, it seems that the consequences of teachers' self-efficacy have not been appropriately explored yet. The research objective was to investigate the consequences of teachers' teaching self-efficacy. The researchers used a qualitative research method. They collected the data through semi-structured interviews with $20 \mathrm{EFL}$ teachers who were selected through purposive sampling. The interviews were content analyzed thematically. Findings showed that self-efficacy has different consequences: pedagogical, learnerrelated, and psychological. Each consequence has several sub-categories. It is concluded that high self-efficacy affects teachers' teaching practices, learners' motivation, and achievement. It also affects teachers' burn-out status, psychological being, as well as their job satisfaction. The findings can be theoretically and pedagogically important to EFL teachers, teacher-trainers, and administrators of educational settings.

Keywords: Self-efficacy, EFL teachers, Consequences, Efficacious teacher
\end{abstract}

\section{Introduction}

Self-efficacy, as a socio-affective concept, was introduced by Bandura (1977). In general terms, efficacy refers to individuals' perceptions and beliefs about their potentiality to perform at a given level of attainment (Bandura, 1977) and how they might deal with the challenges and difficulties and direct their actions (Bandura, 1997). Teacher selfefficacy has been abundantly studied in relation to different factors. Student achievement is also one of these factors which have been confirmed to be positively related to teacher self-efficacy in a plethora of related studies (e.g., Almog \& Shechtman, 2007; Caprara, Barbaranelli, Steca, \& Malone, 2006; Chacon, 2005; Chaplain, 2008; Guo, Piasta, Justice, \& Kaderavek, 2010; Ross, 1992).

More efficacious teachers are better risk-takers who instigate higher levels of standards in their classes, which in turn results in better student achievement. From a broader perspective, teacher self-efficacy has also been reported to be directly related to other factors such as job satisfaction (Moe, Pazzaglia, \& Ronconi, 2010), perfectionism (Comerchero, 2008), and emotional intelligence (Moafian \& Ghanizadeh, 2009;

(c) The Author(s). 2020 Open Access This article is licensed under a Creative Commons Attribution 4.0 International License, which permits use, sharing, adaptation, distribution and reproduction in any medium or format, as long as you give appropriate credit to the original author(s) and the source, provide a link to the Creative Commons licence, and indicate if changes were made. The images or other third party material in this article are included in the article's Creative Commons licence, unless indicated otherwise in a credit line to the material. If material is not included in the article's Creative Commons licence and your intended use is not permitted by statutory regulation or exceeds the permitted use, you will need to obtain permission directly from the copyright holder. To view a copy of this licence, visit http://creativecommons.org/licenses/by/4.0/. 
Rastegar \& Memarpour, 2009). By contrast, it has been argued that teacher efficacy is negatively correlated with teacher burnout (Brouwers, Evers, \& Tomic, 2000; Comerchero, 2008). Synthesizing the related studies, it can be seen that there are still issues related to teachers' self-efficacy which need to be further investigated.

The review of the related studies show that majority of the studies on teachers' self-efficacy are quantitative: either experimental or correlational. However, as selfefficacy is a context-specific phenomenon and multilayered, the positivistic tools of inquiry such as correlational or experimental studies might not be appropriate for studying such a phenomenon. Therefore, interpretative research paradigm and tools such as ethnography and grounded theory might present a better picture of the concept which might lead to EFL teachers' teaching efficacy, from the eyes of EFL teachers.

As Wyatt (2018) believes among the studies on TSE which collected qualitative data, 24 employed mixed methods studies and most of which did not deeply and directly delve with the challenges of eliciting language TSE beliefs, because they used qualitative research methods to collect background or contextual information. Moreover, the local and international researchers mostly tried to investigate the relationship between teachers' self-efficacy and some other variables such professional development, burn-out, personality types (Alibakhshi, 2011), Despite the plethora of studies on EFL teachers' self-efficacy (e.g., Akbari \& Tavassoli, 2014; Akbari \& Moradkhani, 2010; Armor et al., 1976; Ashton \& Webb, 1986; Bartlett et al., 2003; Cakiroglu, 2008; Dembo \& Gibson, 1985; Dussault, 2006; Evans \& Tribble, 1986; Faez \& Valeo, 2012; Gibson \& Dembo, 1984; Guskey, 1984; Hamre et al., 2008; Hoy \& Spero, 2005; Hoy \& Woolfolk, 1990; Karimi, 2011; Moafian \& Ebrahimi, 2015; Pakarinen et al., 2010; Tschannen-Moran \& Hoy, 2001; Woolfolk, 2004; Woolfolk \& Hoy, 1990), it is not known how teachers' self-efficacy might affect their status as teachers and what consequences TSE might have for EFL teachers. The main objective of the present study is to explore what traits/ variables or constructs might be affected as the results of teachers' self-efficacy. More specifically, the following research question was addressed:

What are the consequences of Iranian EFL teachers' self-efficacy?

\section{Review of the related literature}

The related studies are categorized into two categories: studies on teachers' self-efficacy (SE) origin and empirical studies.

\section{Teachers' self-efficacy (TSE) origin}

Self-efficacy is defined as "beliefs in one's capabilities to organize and execute courses of action required to manage prospective situations" (p. 3). It is a concept which deals with people's ability to organize their plans, thoughts, or actions, the efforts they make, and the strategy they use to deal with challenges (TschannenMoran \& Hoy, 2007). With regard to teaching issues, Teachers' Self- efficacy (SE) includes teachers' beliefs in their ability to increase the rate of their students' learning even when they might face obstacles (Ross \& Bruce, 2007). As Bandura (1998) believes, self-efficacy of individuals is constructed through receiving 
information from four sources: enactive mastery experience, vicarious experience, verbal persuasion, and physiological/emotional state.

Self-efficacy beliefs were characterized as the major mediators for our behavior, and importantly, behavioral change. Over the last quarter of the century, Bandura's other works continued to develop more and more and defend the idea that our beliefs in our abilities powerfully affect our behavior, motivation, and ultimately influence our success or failure (Bandura, 1986, 1993, 1995, 1997; Bandura, Caprara, Barbaranelli, Gerbino, \& Pastorelli, 2003). Bandura (1997) suggested that because self-efficacy beliefs were explicitly self-referent in nature and directed toward perceived abilities given specific tasks, they could be powerful predictors of behavior. The related research literature has ever since supported this proposition. Educationally speaking, self-efficacy beliefs are related to academic performance and self-regulated learning for both teachers and students. In the same vein, Tschannen-Moran and Woolfolk Hoy (2001) defined teacher efficacy as a teacher's "judgment of his or her capabilities to bring about desired outcomes of student engagement and learning, even among those students who may be difficult or unmotivated (p.783)."

The study of perceived self-efficacy and its relation to human behavior has extended to the field of education, particularly to the efficacy of teachers. It has also been investigated in terms of its relation to student performance. Numerous researchers have documented the link between student achievement, as the most important manifestation of teacher effectiveness, and teacher efficacy (e.g., Jimmieson, Hannam, \& Yeo, 2010; Lee, Cawthon, \& Dawson, 2013; Skaalvik \& Skaalvik, 2007, 2010). For instance, in a study by Moore and Esselman (1992), teacher efficacy was reported to be highly predictive of learners' achievement on the Iowa Test of Basic Skills, the Canadian Achievement Tests (Anderson, Greene, \& Loewen, 1988), and the Ontario Assessment Instrument Pool (Ross, 1992).

In addition to student-related issues like achievement, sense of efficacy, motivation, etc. researchers have explored the relationships between a teacher's level of efficacy and his or her willingness to adopt instructional innovation (Ghaith \& Yaghi, 1997; Guskey, 1988), lesson presenting and questioning, ability in controlling stress level, desire to stay in the field and teaching commitment (Coladarci, 1992), special education referral (Soodak \& Podell, 1996) and predictions of student success (Tournaki \& Podell, 2005).

\section{Empirical studies on TSE consequences}

Significant positive correlations between efficacy judgments by classroom teachers and their teaching effectiveness were first reported by two large-scale investigations (Berman, McLaughlin, Bass, Pauly, \& Zellman, 1977). In 1976, the Rand Corporation published a study that examined the success of various reading programs and interventions. Teacher efficacy was shown to be strongly related to variations in reading achievement among minority students. In a second study, Rand researchers found teacher efficacy to be a strong predictor of the continuation of federally funded projects after the end of funding (Berman et al., 1977). Teachers' sense of efficacy had a strong positive effect not only on student performance but on the 
percent of the project goals achieved, on the amount of teacher change, and the continued use of project methods and materials after the project ended.

From a broader perspective, teacher self-efficacy has been widely accepted to be related to other factors such as job satisfaction (Moe et al., 2010), perfectionism (Comerchero, 2008), and emotional intelligence (Moafian \& Ghanizadeh, 2009; Rastegar \& Memarpour, 2009). By contrast, teacher efficacy has shown to be negatively related to teacher burnout (e.g., Brouwers et al., 2000; Comerchero, 2008).

Tschannen-Moran, Hoy, and Hoy (1998) also believe that TSE is of much significance to the teachers, because effective teachers seem to have a strong sense of efficacy. They also believe that it is obvious that teacher efficacy is very effective and dramatically contributes to the teachers' pedagogical improvement from different angles.

Tzioti et al. (2010) identified the relationship between job burnout and general selfefficacy, teachers' self-efficacy and group self-efficacy. Moreover, they explored the relationship between job burnout and the three types of self-efficacy with teachers' perceptions of particular work-related values. They found that the three types of self-efficacy were negatively correlated with the three job burnout dimensions. Moreover, Canrinus, Helms-Lorenz, Beijaard, Buitink, and Hofman (2012) investigated how relevant indicators of teachers' sense of professional identity (occupational commitment, job satisfaction, and change in level of motivation) are related. They proposed a model, tested it structural equation modelling (SEM) and refined it using data from 1214 Dutch teachers working in secondary education. Results showed that classroom self-efficacy played a key influencing role in the relationships between the indicators. Using multiple-group SEM, the parameters of the overall model were similar for the novice, experienced and senior teachers in a constrained model.

In the same vein, Shen (2009) explored whether stress coping strategies could be predicted by social support and general self-efficacy. Five hundred and thirty primary and secondary teachers were selected and they completed measures of coping strategies, general self-efficacy and social support. The results showed that teachers' general selfefficacy and social support had direct and indirect predictive effects on different coping strategies, and they had more significant predictive effects on certain types of coping strategies. Teachers with higher general self-efficacy and social support tended to adopt adaptive coping strategies or oriented coping strategies.

Tzur, Ganzach, and Pazy (2016) addressed the controversy regarding the sign of the effect of self-efficacy on performance. They proposed that when reward is high, self-efficacy has a positive effect on performance, whereas when reward is low, it has a negative effect. They tested the hypothesis in three experiments in which reward and self-efficacy were manipulated and performance was measured using different manipulations and tasks in both within-factor and between-factor designs. They found that reward moderates the effect of self-efficacy on performance. When reward was high, the effect of self-efficacy on performance was positive, whereas when reward was low, the effect of self-efficacy on performance was negative.

Very recently, Mustafa, Glavee-Geo, Gronhaug, and Almazrouei (2019) explored how the two core structural components-formalization and centralization-separately and jointly affected employee self-efficacy and how they interact with selfefficacy to influence employee task performance. The study further examines the extent to which structure weaves its influence on individual performance through 
perceptions of self-efficacy. Data from 120 Pakistani public sector employees were analyzed using partial least squares structural equation modelling (PLS-SEM) and polynomial regression to assess the hypothesized relationships. Results showed that formalization is positively associated with self-efficacy while centralization has a negative association, and such an improvement/attenuation in self-efficacy is partly transformed into performance improvements. They also found that self-efficacy and performance relationship are diminished under conditions of high formalization and high centralization.

\section{Methodology}

Method

Methodology needs to be best aligned with a research interest, ontology and epistemology (Cohen, Manion, \& Morrison, 2018). Therefore, the researchers employed a phenomenological inquiry to explore the antecedents of language teachers from their own eyes. A phenomenology inquiry "is an attempt to deal with inner experiences unproved in everyday life” (Merriam, 2002, p. 7). This qualitative research approach describes lived people's experience of a phenomenon. In this study, the phenomenon is self-efficacy consequences. The researchers employed this method to help identify the meaning behind the human experience as it related to a phenomenon or notable collective occurrence (Creswell, 2013).

\section{Participants}

Purposive sampling was used to recruit teachers who have been evaluated as efficacious based on their scores on the self-efficacy scale. This sampling method helps the researchers to have a homogenous sample of participants who have all experienced the phenomenon (Creswell, 2013). Participants were all selected from Zabankedeh Meli language institute, which helped the researchers to maintain homogeneity of the sample. They were selected in two steps. They were contacted via either telephone or e-mail and were asked to read and sign a consent form. After obtaining the written consent, a

Table 1 Demographic characteristics of participants

\begin{tabular}{lc}
\hline Variable & Number \\
\hline Certification & 12 \\
BA (Bachelor of Arts) of TEFL & 8 \\
MA (Masters of Arts) of TEFL & \\
Gender & 10 \\
Male & 10 \\
Female & \\
Teaching experience & 7 \\
$5-10$ & 7 \\
$10-15$ & 6 \\
$15-20$ & 7 \\
Age & \\
$30-34$ & 8 \\
$34-38$ & 5 \\
$38-42$ & 7 \\
\hline
\end{tabular}


pseudonym was assigned to each participant. The participants were selected in two rounds. In the first round, efficacious teachers were screened. In the second round, the efficacious teachers were finalized for inclusion in the study and interviewed in the schools at which they teach. The data saturation occurred when the 20th teacher was interviewed. The demographic characteristics of participants are given in Table 1.

\section{Instruments}

In this study, two instruments were used: Teachers' Sense of Efficacy Scale (long form) developed by Tschannen-Moran and Hoy (2007) and interview checklist. The teachers' sense of Efficacy scale was used to estimate the participants' sense of efficacy. It consisted of 24 items. It also consists of three subscales: efficacy in student engagement (8 items), efficacy in instructional strategies: 8items, and efficacy in classroom management (8 items). This instrument was used as a scale for screening efficacious teachers. It enjoyed an acceptable level of internal consistency $(r=0.89)$. In addition, a semistructured interview checklist was developed, carefully worded, reviewed by five teacher educators known as experts in qualitative research methodology and teacher education, and edited based on the experts' feedback. Each teacher was interviewed privately in his regular classroom. The interviewer audiotaped all interviews for accuracy. The interview checklist included questions addressing the teachers' feelings about efficacious teachers and the teaching areas which are affected by high degree of self-efficacy.

Throughout the process of the interviews, follow-up questions were asked as needed to clarify responses and encourage elaboration (See Table 2).

The interviews with the participants were conducted in English; the teachers' major and difficult terminology associated with self-efficacy was avoided. In order to elicit teachers' in-depth perceptions, the interviewer allowed the conversation to move on smoothly in a more interactive manner. All Data collection was completed over a period of 3 months and ended up the data saturation, i.e., when no further new

Table 2 Interview protocol

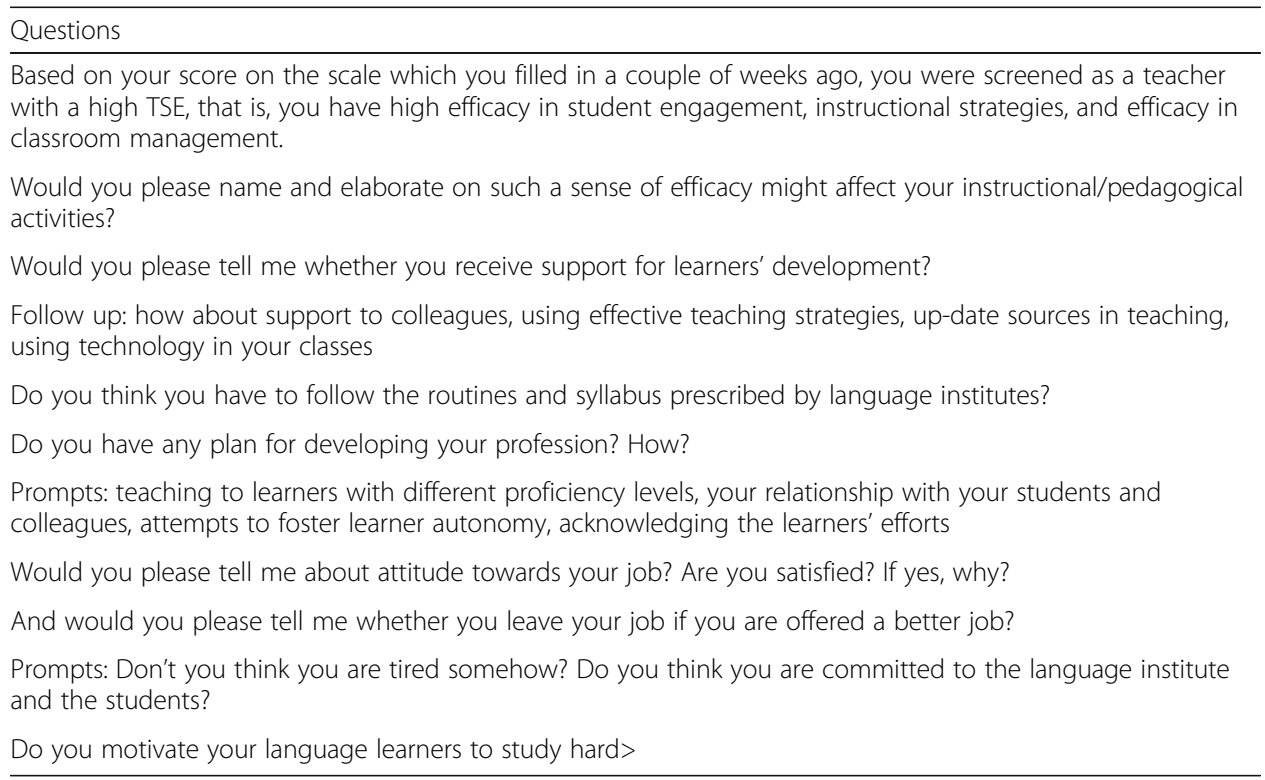


information or themes emerged to add to the researchers' understanding of the consequences of TSE.

\section{Data analysis}

All interviews were transcribed word by word. The data were analyzed through following Moustakas's (1994) method of inductive data analysis. First, each transcript was read twice to immerse the researchers in the data. Then, all transcripts were reread, and memos were audio-recorded to deeply immerse the researcher (the corresponding author of the study collected and analyzed the data and highlighted key concept). After initial immersion in the data analysis process, the transcripts were first analyzed through open coding and axial coding (Strauss \& Corbin, 1998). All interview transcripts were transcribed and coded by the first author. Then, through peer debriefing sessions with an expert in teacher education who has published several qualitative papers on teacher education, the codes were checked, and inter-coder consistency was estimated. The two coders have agreed on all extracted codes. Finally, the extracted themes were identified by rereading the transcripts to verify that they and their accompanying constituents were clearly expressed and exactly compatible with the interviewees' words. Each theme was exemplified by at least one direct quotation from one of the interviewees.

\section{Results}

Interviews with 20 male and female teachers were content analyzed. The consequences were thematically categorized into three categories: Teaching/ learning process, learner-related, and teachers' psychological consequences.

\section{Teaching/learning processes}

Results of the content analysis indicated that teachers' self-efficacy has positive consequences for teachers' instructional behaviors and strategies. More specifically, this domain consists of 3 sub-domains: pedagogical/instructional support, classroom management, and emotional support. Each of these subcategories is described as follows.

Table 3 The sub-categories of pedagogical support consequence

\begin{tabular}{lll}
\hline Consequence & Dimensions & $\mathrm{N}(\%)$ \\
\hline Pedagogical/Instructional support & Overall instructional development & $17(85 \%)$ \\
& Support for learners' language development & $16(80 \%)$ \\
& Using effective instructional strategies & $16(80 \%)$ \\
& Employing updated learning-centered approaches & $15(75 \%)$ \\
& Using Computer and Technology in Classes & $15(75 \%)$ \\
& Instructional support to the colleagues & $14(70 \%)$ \\
& Professional Development & $12(60 \%)$ \\
& Teacher autonomy & $11(55 \%)$ \\
\hline
\end{tabular}




\section{Pedagogical/instructional support}

The participants stated that the pedagogical behaviors, strategies, and practices which they use to support the language learners' affective, cognitive, and academic development are greatly determined by their self-efficacy. This theme consists of seven subthemes that are presented in the following Table 3.

Overall instructional development Participants of the study suggested that TSE contributes to different instructional practices such as process-oriented instruction, the ability to use effective teaching strategies, engaging in professional learning activities, trying new teaching techniques to improve their practices, and changing their practice to promote process-oriented student learning. The following quotations exemplify the theme:

I always try to use very effective strategies for teaching my students, and sometimes I do my best to know about the effective strategies which the other language teachers in the other countries use to teach language learners. (p.8)

Support for learners' language development About $70 \%$ of the participants suggested that teachers' self-efficacy can greatly contribute to their teaching quality as well as the teaching strategies they use to help the language learners develop language skills and sub-skills. More specifically, they stated that high efficacious teachers use communicatively oriented language strategies; consequently, the communicative competence of the students develops drastically. One of the participants argued:

My teaching at present is quite different from my teaching in the past. Now my belief in my abilities is of much help. I dare to experience recent teaching strategies recommended as effective for communicative competence, and I found all useful. (p.2)

Employing effective instructional strategies As reported by $80 \%$ of the participants, teachers with high teaching efficacy attempt to use teaching methods and strategies congruent with their practices. The following quotation exemplifies the theme:

I observed that some teachers who have a strong belief about their teaching abilities are totally different from those who do not believe in their ability in teaching in terms of the strategies they use for teaching. That is, they use more effective teaching strategies.

Employing updated learning-centered approaches Another consequence of TSE is a teacher's use of updated teaching approaches. Participants suggested that high self- efficacy contributes to the use of innovative teaching approaches and methods such as learner-oriented approaches to teaching. One of the participants argued: 
As I believe I can do my job well, I follow the more recent teaching methods which focus on learner-centered issues in teaching.

Using computer and technology in classes Results also showed that $65 \%$ of the participants suggested self-efficacious teachers frequently use a computer and educational technology in their classes.

I always use a computer and technology in my classes. While teaching, I download from the internet whatever seems to be related to the topic I teach to my students.

Instructional support to the colleagues The next issue related to the instructional support is that (as mentioned by $60 \%$ of the participants), teachers with high self- efficacy support their colleagues in terms of teaching strategies, activities, and anything related to teaching, if necessary.

Some colleagues, while facing problems in teaching or managing classrooms, come to me and ask for the solutions, and I transfer my knowledge and experience to them.

Professional development Results, as reported by $50 \%$ of the participants, indicate that teachers with high self-efficacy either formally or informally do their best to develop their profession.

As I could teach language learners with various language proficiency levels, I tried to develop my teaching through attending teacher training centers such as DELTA and CELTA, as well as relevant workshops.

Teacher autonomy Teacher autonomy, as suggested by $70 \%$ of the participants, is another consequence of TES, which is related to instructional support. That is, efficacious teachers have autonomy in selecting teaching materials, teaching activities, as well as assessment activities.

I think I am quite able to make a change in the content of the syllabus and types and time of assessment suggested by institutes and schools. (p.20)

\section{Classroom process (management)}

Classroom management is mainly perceived as an aspect of classroom processes which is related to how teachers try to manage students' behavior and teaching time, and provide materials and lessons that increase learning opportunities. Within this domain, participants suggested three aspects that are affected by teachers' self-efficacy: teaching to exceptional students, students' behavior 
Table 4 The subcategories of classroom management consequences

\begin{tabular}{|c|c|c|c|}
\hline Consequence & \multicolumn{2}{|l|}{ Dimensions } & $\mathrm{N} /(\%)$ \\
\hline \multirow[t]{6}{*}{ Classroom Process (management) } & \multicolumn{2}{|c|}{ Teaching to exceptional /heterogeneous students } & $17(85 \%)$ \\
\hline & \multicolumn{2}{|c|}{ Classroom Behavior Management } & $15(75 \%)$ \\
\hline & \multirow[t]{4}{*}{ Emotional Support } & Classroom Emotional Climate & $13(65 \%)$ \\
\hline & & Student-Teacher Relationship Quality & $13(65 \%)$ \\
\hline & & Appreciating students' perspectives & $12(60 \%)$ \\
\hline & & Promoting learner autonomy & $12(60 \%)$ \\
\hline
\end{tabular}

management, and emotion regulation. A detailed description of each theme is presented in the following Table 4.

Teaching to exceptional/heterogeneous students Self-efficacious teachers suggested that they are less anxious and more capable of teaching to highly talented language learners and those with learning disabilities. They also suggested that they are more tolerant of rude students; they also rarely exclude such students from their class.

I used to teach to demotivated language learners, less proficient ones and upperintermediate language learners (p.19)

Classroom behavior management Participants suggested that TSE affects teachers' ability to organize students' behaviors while teaching. Moreover, they argued that they could cope with students' social-emotional behavior. That is, they are able to cope better with behavioral problems such as low achievement, social rejection, shyness, disobedience, hostility, and hyperactivity.

At the beginning of my teaching at language institutes, I couldn't easily cope with the behavioral problems of the language learners in my class. But now I am quite successful in coping with almost all behavioral problems of language learners (p.18)

Emotional support The third consequence of classroom management is teachers' emotional support. Emotion support is teachers' ability to create caring relationships with students, create learning situations in which language learners feel secure to learn, and acknowledge their feelings and opinions. This aspect consists of several sub-categories such as emotional climate, the quality of the student-teacher relationship, or

Table 5 The sub-categories of emotional support consequence

\begin{tabular}{lll}
\hline Consequence & Dimensions & $\mathrm{N}(\%)$ \\
\hline Emotional support & Classroom emotional climate & $17(85 \%)$ \\
& Student-Teacher relationship quality & $15(75 \%)$ \\
& Valuing students' perspectives & $14(70 \%)$ \\
& Promoting learner autonomy & $13(65 \%$ \\
\hline
\end{tabular}


valuing student perspectives, promoting learner autonomy. The sub-categories are presented in the following Table 5.

\section{Classroom emotional climate}

High self-efficacy teachers reported that they could create a supportive environment in the classroom accompanied by enthusiasm, warmth, q responsiveness, teacher support, and effective use of classroom time.

\section{Student-teacher relationship quality}

Another consequence of TSE, which is related to teachers' emotional support, is the quality of the student-teacher relationship. About $65 \%$ of the participants argued that they have a very friendly relationship with the students in and out of language institutes. One of the interviewees stated:

I have a friendly relationship with my students; I have their phone numbers and emails. I join their telegram groups, sometimes I go to the park with my students and have free discussions with them.

\section{Appreciating students' perspectives}

About $60 \%$ of the participants argued that they are willing and able to appreciate the students' views, interests, and motivations. That is, while selecting materials and making decisions about teaching activities; they take into account the language learners' interests, motivations, and perspectives.

I know that learners' perspectives if appreciated by teachers, can be very insightful for the teachers. I try to see language learners are motivated or nor and what perspectives they might have about the teaching/learning process.

\section{Promoting learner autonomy}

Next to teachers' appreciation for students' perspectives is promoting learner autonomy by language teachers. About $60 \%$ of the participants believed that they do their best to promote the language learners' learner autonomy. The following quotation exemplifies the theme:

I know that through limited time allocated to teaching English at schools/institutes, it is not possible for language learners to learn English; therefore I teach learning strategies to help them become autonomous

Table 6 The learner-related consequences

\begin{tabular}{lr}
\hline Consequence & N (\%) \\
\hline & Learner-related \\
General achievement & $17(85 \%)$ \\
Motivation/attitude & $17(85 \%)$ \\
Autonomy & $15(75 \%)$ \\
\hline
\end{tabular}




\section{Learner/student-related consequences}

The most common consequence of TSE for student outcomes was based on students' achievement (Table 6).

\section{General achievement}

Participants also argued that teachers' self-efficacy significantly contributes to the students' general academic achievement. Most particularly speaking, TSE affects language learners' general knowledge and communicative competence.

\section{Students' motivation}

The next finding was that teachers' self-efficacy affects students' motivation, most particularly students' self-efficacy, engagement, and school investment.

\section{Students' autonomy}

The next extracted consequence of TSE is learner autonomy. Participants of the study argued that high efficacious teachers promote learner autonomy among language learners.

\section{Teachers' psychological consequences}

The next finding of the study was that teachers' TSE affects their psychological being. Among the related variable, four psychological traits were reported by more than $65 \%$ of the participants, which are presented in the following Table 7.

\section{Burnout filtering}

About $85 \%$ of the participants argued the rate of burnout among them is very low. Therefore, it could be argued that TSE contributes to their psychological well-being and, in fact, burnout is, to a great extent, filtered.

\section{I never feel tired of teaching English though I teach 30 hours a week}

\section{Teachers' job satisfaction}

Next to burnout, $85 \%$ of the participants stated teachers' job satisfaction is one of the psychological outcomes of teachers' TSE.

I never like to change my job. I guess even if I find a job with a very good salary I don't like to quit this job.

Table 7 Psychological consequences of TSE

\begin{tabular}{lr}
\hline Consequence & N (\%) \\
\hline & \\
Burnout filtering & \\
Job satisfaction & $17(85 \%)$ \\
Teacher commitment & $17(85 \%)$ \\
Teacher retention & $15(75 \%)$ \\
\hline
\end{tabular}




\section{Teachers' commitment}

Seventy-five percent of the participants argued that TSE significantly affects their commitment to institutes (schools), students, and society. Participants believed that TSE is a positive predictor of occupational commitment, irrespective of the school or institute in which they teach.

I do my best to contribute to the progress of the institute. I really like to make a change in the learners' academic progress and train good citizens

\section{Teacher retention}

Sixty-five percent of the participants argued that only EFL teachers with high selfefficacy attempt to remain longer in teaching professions. Moreover, participants argued that the level of absenteeism among high efficacious teachers is very low.

I don't like to leave the situations in which I teach cause I am able to meet the standard expectations of the institutes in which I teach.

\section{Discussion}

The purpose of the study was to explore the consequences of EFL teachers' self efficacy. Interviews were content analyzed. The consequences were thematically categorized into three categories: Teaching/ learning process consequences, learnerrelated consequences, and teachers' psychological consequences. Regarding the first category, results showed that teachers' self-efficacy has positive consequences for teachers' instructional behaviors and strategies: pedagogical/instructional support, classroom management, and emotional support. This finding is consistent with the findings of some scholars who suggest that the instructional strategies, behaviors, and practices which teachers use to encourage students' cognitive development might partly be determined by their self-efficacy (e.g., Beaman \& Wheldall, 2000; Tschannen-Moran \& Hoy, 2007).

Another main finding of the study was that TSE contributes to different general instructional practices. Among these consequences are process-oriented instruction, the ability to employ effective teaching strategies, and engagement in professional learning activities, trying out new approaches to improve their practices, and changing their practice to promote process-oriented student learning. This finding verifies the findings of some other related studies. Therefore, in line with the findings of the present and related studies, it can be argued that teachers with great sense of self-efficacy try new ideas and are more willing to test and practice novel teaching methods so that they can bring about a change in students' academic uptake (Coladarci, 1992; Ghaith \& Yaghi, 1997; Lee et al., 2013). Therefore, in line with these studies, it could be argued that self-efficacious teachers are more enthusiastic about and dedicated to teaching. In addition, in line with Ross (1998) and Soodak and Podell (1993), it can be argued that highly efficacious teachers are more open to innovations and more willing to adapt teaching innovations in order to meet the needs of their students better. 
Findings also revealed that EFL teachers' TSE affects their support for learners' language development and the use of updated learning-centered approaches. These findings are consistent with findings of couple of related studies (Chacon, 2005) sense of self-efficacy to implement didactic innovations in the classroom and use classroom management approaches and adequate teaching methods that encourage students' autonomy and reduce custodial control (Guskey, 1998) to take responsibility for students with special learning needs (Allinder, 1995) and to manage classroom problems (Chacon, 2005). Teachers with a high sense of efficacy have the capacity to accept more challenging tasks, determination, show more stamina facing difficulties, and become less anxious). Consistent with Ross's, 1994 conclusions, teachers who believe more in the effect of teaching on students' learning expect the higher academic success of their students than those who believe less in this fact (Ross, 1994). Teacher's self-efficacy influences their motivation and performance together with students' results (Bandura, 1997).

The impact of teachers' self-efficacy on their use of computers and technology in classes was another finding of the study. This finding is consistent with several related studies (Tschannen-Moran et al., 1998; Tsitouridou \& Vryas, 2004). The common finding of the present study was that self-efficacy affects the use of technology teachers.

With regard to classroom management, participants suggested three aspects are affected by teachers' self-efficacy: teaching to exceptional students, students' behavior management, and emotion regulation. This finding is consistent with the findings of Almog and Shechtman (2007). Accordingly, it can be argued that efficacious in-service teachers can easily cope better with problematic behaviors, most particularly low achievement, hostility, hyperactivity, shyness, disobedience, (Yoon, 2004), and students' bullying behavior (Lambert, McCarthy, O'Donnell, \& Wang, 2009). In line with some other scholars (e.g., Morris-Rothschild \& Brassard, 2006), it could be strongly argued that TSE positively contributes to teachers' behavior, overall classroom management strategies, and their approaches to managing student-teacher conflicts.

Another finding was that teachers' TSE affects student-teacher relationship quality. This finding is consistent with Jimmieson et al.'s (2010) study on TSE, who argue that efficacious teachers have close relationships with regular preschool students. Appreciating students' perspectives and promoting learner autonomy was also found to be affected by EFL teachers' TSE. That is, high efficacious teachers, involve language learners in teaching and processes such as making decisions about types of syllabi, classroom management, and evaluation. Therefore, in line with (Allinder, 1995; Guskey, 1981), it can be inferred that high efficacious teachers do not criticize the students for their mistakes and accept their suggestion with open arms.

The second main categories of the TSE consequences are learner-related. To be more specific, findings indicated that teachers' TSE affects language learners' general achievement, motivation, and autonomy. Consistent findings were also reported by some scholars (e.g., Caprara, Barbaranelli, Borgogni, \& Steca, 2003; Caprara et al., 2006; Chaplain, 2008) who found that students taught by teachers with higher TSE have better academic achievement than those taught by teachers with a lower sense of efficacy. Teachers' TSE impact on the students' motivation is also consistent with the existing literature (e.g., Reyes, Brackett, Rivers, White, \& Salovey, 2012; Ross, Hogaboam-Gray, \& Hannay, 2001; Thoonen, Sleegers, Oort, Peetsma, \& Geijsel, 2011) which shows that 


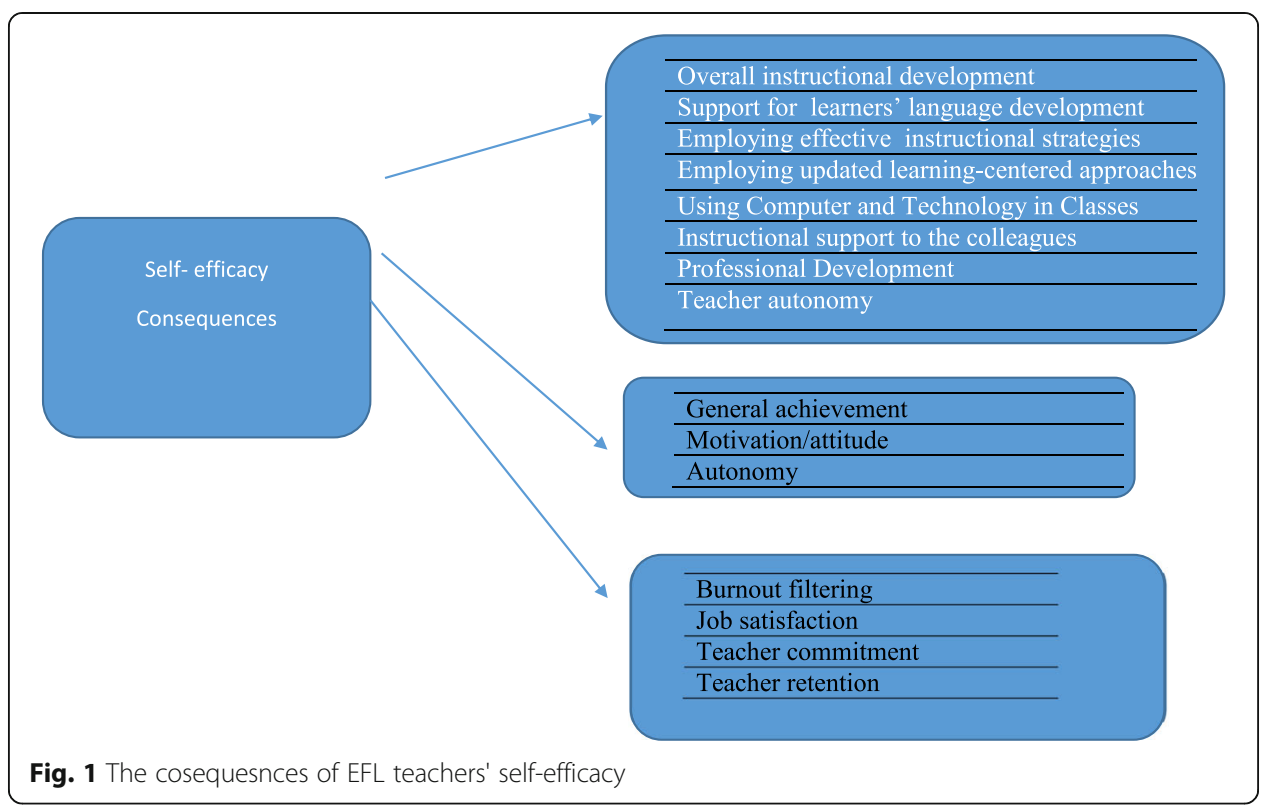

teachers' self-efficacy more significantly predicts the students' motivation (e.g., Thoonen et al., 2011).

Teachers' psychological being is the last trait that is affected by teachers' TSE. Among the related variables were four psychological traits reported: burnout reduction, job satisfaction, teacher commitment, and teacher retention. This finding is consistent with Hultell, Melin, \& Gustavsson's, 2013 work, which indicated that decreases in TSE were associated with teachers' burnout levels. That is, high TSE reflects low-level burnout, while low TSE reflect high-level burnout (Skaalvik \& Skaalvik, 2007, 2011, 2019). The findings are also consistent with Avanzi et al. (2012), who stated that there was a negative correlation between Italian teachers' efficacy student- and work-related burnout. The main findings can be presented in the following Fig. 1.

\section{Conclusions and implications}

It can be concluded that teachers' TSE has three macro-consequences: pedagogical, learner-related, and psychological consequences. Each of these consequences has some sub-consequences. The main consequences are summarized and presented as follows:

The study has some practical implications for EFL teachers, teacher trainers, teacher education programs at universities and educators in general. This study helps teachers and practitioners in EFL teaching field to extend their understanding of the significance of TSE and its impact on the effectiveness of instruction in general, their support for learners' language development, their use of effective instructional strategies, their use of updated learning-centered approaches, their use of technology and computer in classes, their instructional support to colleagues, their professional development as well as autonomy.

This study also helps practitioners and EFL teachers to extend their knowledge about the impact of TSE on the language learners' motivation, autonomy, and their language development. The findings can also raise the teachers' awareness about their 
psychological well-being, including burnout, job satisfaction, as well as their organizational commitment. The findings can also be used for reforming in-service training courses. That is, such courses can be redesigned in different ways, which foster and promote teachers' self-efficacy beliefs. Given that teachers' self-efficacy is affected by some variables related to the institutions, the administrators are recommended to consider designing professional development activates/opportunities through which teachers might have the chance to collaborate and participate in decision making and planning processes. Administrators can also use managerial strategies to foster the positive climate of the schools and institutes and teacher autonomy. Finally, administrators can use the findings to foster teacher autonomy among the language teachers and provide the teachers with an appropriate and acceptable quality of work-life through which teachers feel they have job security and the chance to promote.

\section{Limitations and suggestions for further studies}

While undertaking the study, the researchers faced some limitations. First, the they were not able to explore the antecedents of teachers' SE. They were not able to show the relationship between each of the extracted consequences and teachers' SE. Therefore, the other researchers are recommended to investigate the relationship between teachers' TSE and any of its consequences and antecedents through structural equation modeling. In the present study, teachers' teaching experience, major personality types, and educational backgrounds were not taken into account. The other researchers are recommended to replicate the present study, either qualitatively and quantitatively, to see whether the findings differ across these variables or not.

\footnotetext{
Authors' contributions

Corresponding author wrote the whole parts of the paper. The second author clarified the term of teachers' selfefficacy and developed the interview protocol and recoded the qualitative data. The third author summarized the used references, arranged the interviews time, and audio-taped the interviews. The author(s) read and approved the final manuscript.
}

Funding

Funding is not applicable to this study.

\section{Availability of data and materials}

Please contact the corresponding author for data requests.

Competing interests

The authors declare that they have no competing interests.

\section{Author details}

${ }^{1}$ Allameh Tabataba'i University, Olympics dehkedeh, Varezesh Street, Tehran, Iran. ${ }^{2}$ Department of Psychology and Educational Sciences, Yasouj University, Yasouj, Iran. ${ }^{3}$ Kahazar Higher Education Institute, Mahmudabad, Mazandaran, Iran.

Received: 10 March 2020 Accepted: 24 June 2020

Published online: 10 December 2020

References

Akbari, R., \& Moradkhani, S. (2010). Iranian English teachers' self-efficacy: Do academic degrees and experience make a difference? Pazhuhesh-e Zabanha-ye Khareji, 56, 25-47.

Akbari, R., \& Tavassoli, K. (2014). Developing an ELT context-specific teacher efficacy instrument. RELC Journal, 45(1), 27-50 https://doi.org/10.1177/0033688214523345.

Alibakhshi, G. (2011). On the impacts of gender and personality types on Iranian EFL teachers' teaching efficacy and teaching activities preferences. Iranian Journal of Applied Linguistics (IJAL), 14(1), 1-22.

Allinder, R. M. (1995). An examination of the relationship between teacher efficacy and curriculum-based measurement and student achievement. Remedial \& Special Education, 16(4), 247-255 https://doi.org/10.1177/074193259501600408.

Almog, O., \& Shechtman, Z. (2007). Teachers' democratic and efficacy beliefs and styles of coping with behavioral problems of pupils with special needs. European Journal of Special Needs Education, 22, 115-129 https://doi.org/10.1080/ 08856250701267774. 
Anderson, R. N., Greene, M. L., \& Loewen, P. S. (1988). Relationships among teachers' and students' thinking skills, sense of efficacy. and student achievement. The Alberta Journal of Educational Research, 34, 148-165.

Armor, D., Conroy-Oseguera, P., Cox, M., King, N., McDonnell, L., Pascal, et al. (1976). Analysis of the school preferred reading programs in selected Los Angeles minority schools (report no. R-2007-LAUSD). Santa Monica: Rand Corporation (ERIC Document Reproduction Service No. 130 243).

Ashton, P. T., \& Webb, R. B. (1986). Making a difference: Teachers' sense of efficacy and student achievement. New York: Longman.

Avanzi, L., Miglioretti, M., Velasco, V., Balducci, C., Vecchio, L., Fraccaroli, F., \& Skaalvik, E. M. (2012). Cross-validation of the Norwegian teacher's self-efficacy scale (NTSES). Teaching and Teacher Education, 31, 69-78 https://doi.org/10.1016/j.tate. 2013.01.002.

Bandura, A. (1977). Self-efficacy: Toward a unifying theory of behavioral change. Psychological Review, 84(2), 191-215.

Bandura, A. (1986). Social foundations of thought and action: A social cognitive theory. Englewood Cliffs: Prentice-Hall.

Bandura, A. (1993). Perceived self-efficacy in cognitive development and functioning. Educational Psychologist, 28(2), 117-148.

Bandura, A. (1995). Self-efficacy in changing societies. Cambridge: Cambridge University Press.

Bandura, A. (1997). Self-efficacy: The exercise of control. New York: W. H. Freeman and Company.

Bandura, A. (1998). Health promotion from the perspective of social cognitive theory. Psychology and Health, 13, 623-649.

Bandura, A., Caprara, G. V., Barbaranelli, C., Gerbino, M., \& Pastorelli, C. (2003). Role of affective self-regulatory efficacy in diverse spheres of psychosocial functioning. Child Development, 74, 769-782.

Bartlett, S. J., Piedmont, R., Bilderback, A., Matsumoto, A. K., \& Bathon, J. M. (2003). Spirituality, well-being, and quality of life in people with rheumatoid arthritis. Arthritis and Rheumatism (Arthritis Care and Research), 49, 778-783.

Beaman, R., \& Wheldall, K. (2000). Teachers' use of approval and disapproval in the classroom. Educational Psychology, 20(4), 431-446 https://doi.org/10.1080/713663753.

Berman, P., McLaughlin, M., Bass, G., Pauly, E., \& Zellman, G. (1977). Federal programs are supporting educational change. Vol. VII factors affecting implementation and continuation (report no. R-1589/7-HEW). Santa Monica: The Rand Corporation (ERIC Document Reproduction Service No.140 432).

Brouwers, A., Evers, W., \& Tomic, W. (2000). A longitudinal study of teacher burnout and perceived self-efficacy in classroom management. Teaching and Teacher Education, 16, 239-253.

Cakiroglu, E. (2008). The teaching efficacy beliefs of pre-service teachers in the USA and Turkey. Journal of Education for Teaching, 34(1), 33-44 https://doi.org/10.1080/02607470701773457.

Canrinus, E. T., Helms-Lorenz, M., Beijaard, D., Buitink, J., \& Hofman, A. (2012). Self-efficacy, job satisfaction, motivation and commitment: Exploring the relationships between indicators of teachers' professional identity. European Journal of Psychology of Education, 27(1), 115-132 https://doi.org/10.1007/s10212-011-0069-2.

Caprara, G. V., Barbaranelli, C., Borgogni, L., \& Steca, P. (2003). Efficacy beliefs as determinants of teachers' job satisfaction. Journal of Educational Psychology, 95, 821-832 https://doi.org/10.1037/0022-0663.95.4.821.

Caprara, G. V., Barbaranelli, C., Steca, P., \& Malone, P. S. (2006). Teachers' self-efficacy beliefs as determinants of job satisfaction and students' academic achievement: A study at the school level. Journal of School Psychology, 44, 473-490 https://doi. org/10.1016/j.jsp.2006.09.001.

Chacon, C. T. (2005). Teachers' perceived efficacy among English as a foreign language teachers in middle schools in Venezuela. Teaching and Teacher Education, 21, 257-272 https://doi.org/10.1016/j.tate.2005.01.001.

Chaplain, R. P. (2008). Stress and psychological distress among trainee secondary teachers in England. Educational Psychology, 28, 195-209 https://doi.org/10.1080/01443410701491858.

Cohen, L., Manion, L., \& Morrison, K. (2018). Research methods in education. New York: Routledge.

Coladarci, T. (1992). Teachers' sense of efficacy and commitment to teaching. Journal of Experimental Education, 60, 323-337 https://doi.org/10.1080/01443410701491858.

Comerchero, V. (2008). Gender, tenure status, teacher efficacy, perfectionism, and teacher burnout (unpublished doctoral dissertation). New York: Fordham University.

Creswell, J. W. (2013). Qualitative inquiry and research design: Choosing among five approaches. Thousand Oaks: Sage Publications.

Dembo, M., \& Gibson, S. (1985). Teachers' sense of efficacy: An important factor in school achievement. The Elementary School Journal, 86(2), 173-184.

Dussault, M. (2006). Teachers' self-efficacy and organizational citizenship behaviors. Psychological Reports, 98, 427-432 https:// doi.org/10.1086/461441.

Evans, E., \& Tribble, M. (1986). Perceived teaching problems, self-efficacy, and commitment to teaching among preservice teachers. The Journal of Educational Research, 80(2), 81-85 https://doi.org/10.1080/00220671.1986.10885728.

Faez, F., \& Valeo, A. (2012). TESOL teacher education: Novice teachers' perceptions of their preparedness and efficacy in the classroom. TESOL Quarterly, 46(3), 450-471 https://doi.org/10.1002/tesq.37.

Ghaith, G., \& Yaghi, M. (1997). Relationships among experience, teacher efficacy, and attitudes toward the implementation of instructional innovation. Teaching and Teacher Education, 13(4), 451-458 https://doi.org/10.1016/50742-051X(96)00045-5.

Gibson, S., \& Dembo, M. (1984). Teacher efficacy: A construct validation. Journal of Educational Psychology, 76(4), 569-582 https://doi.org/10.1037/0022-0663.76.4.569.

Guo, Y., Piasta, S. B., Justice, L. M., \& Kaderavek, J. N. (2010). Relations among preschool teachers' self-efficacy, classroom quality, and children's language and literacy gains. Teaching and Teacher Education, 26(4), 1094-1103 https://doi.org/10. 1016/j.tate.2009.11.005.

Guskey, T. R. (1981). Measurement of responsibility teachers assumes for academic successes and failures in the classroom. Journal of Teacher Education, 32(1), 44-56 https://doi.org/10.1177/002248718103200310.

Guskey, T. R. (1984). The influence of change in instructional effectiveness upon the affective characteristics of teachers. American Educational Research Journal, 21(2), 245-259 https://doi.org/10.2307/1162442.

Guskey, T. R. (1988). Teacher efficacy, self-concept, and attitudes toward the implementation of instructional innovation. Teaching and Teacher Education, 4(1), 63-69 https://doi.org/10.1016/0742-051X(88)90025-X.

Guskey, T. R. (1998). Making time to train your staff. The School Administrator, 55(7), 35-37. 
Hamre, B. K., Pianta, R. C., Downer, J. T., \& Mashburn, A. J. (2008). Teachers' perceptions of conflict with young students: Looking beyond problem behaviors. Social Development, 17(1), 115-136 https://doi.org/10.1111/j.1467-9507.2007.00418.x.

Hoy, A. W., \& Spero, R. B. (2005). Changes in teacher efficacy during the early years of teaching: A comparison of four measures. Journal of Teaching and Teacher Education, 21(4), 343-356 https://doi.org/10.1016/j.tate.2005.01.007.

Hoy, W. K., \& Woolfolk, A. H. (1990). Socialization of student teachers. American Educational Research Journal, 27(2), 279-300 https://doi.org/10.3102/00028312027002279.

Hultell, D., Melin, B., \& Gustavsson, J. P. (2013). Getting personal with teacher burnout: A longitudinal study on the development of burnout using a person-based approach. Teaching and Teacher Education, 32, 75-86.

Jimmieson, N. L., Hannam, R. L., \& Yeo, G. B. (2010). Teacher organizational citizenship behaviors and job efficacy: Implications for student quality of school life. British Journal of Psychology, 101(4), 453-479 https://doi.org/10.1348/000712609X470572.

Karimi, M. N. (2011). The effects of professional development initiatives on EFL teachers' degree of self-efficacy. Australian Journal of Teacher Education, 36(6), 50-62 https://doi.org/10.14221/ajte.2011v36n6.6.

Lambert, R. G., McCarthy, C., O'Donnell, M., \& Wang, C. (2009). Measuring elementary teacher stress and coping in the classroom: Validity evidence for the classroom appraisal of resources and demands. Psychology in the Schools, 46(10), 973-988 https://doi.org/10.1002/pits.20438.

Lee, B., Cawthon, S., \& Dawson, K. (2013). Elementary and secondary teacher self-efficacy for teaching and pedagogical conceptual change in a drama-based professional development program. Teaching and Teacher Education, 30(1), 84-98 https://doi.org/10.1016/j.tate.2012.10.010.

Merriam, S. B. (2002). Introduction to qualitative research. In S. B. Merriam, \& Associates (Eds.), Qualitative research in practice: Examples for discussion and analysis. San Francisco: Jossey-Bass.

Moafian, F., \& Ebrahimi, M. R. (2015). An empirical examination of the association between multiple intelligences and language learning self-efficacy among TEFL university students. Iranian Journal of Language Teaching Research, 3(1), 19-36.

Moafian, F., \& Ghanizadeh, A. (2009). The relationship between Iranian EFL teachers' emotional intelligence and their selfefficacy in language institutes. System, 37(4), 708-718 https://doi.org/10.1016/j.system.2009.09.014.

Moe, A., Pazzaglia, F., \& Ronconi, L. (2010). When being able is not enough: The combined value of positive affect and selfefficacy for job satisfaction in teaching. Teaching and Teacher Education, 26(5), 1145-1153 https://doi.org/10.1016/j.tate. 2010.02.010

Moore, V., \& Esselman, M. (1992). Teacher efficacy, empowerment, and focused instructional climate: Does student achievement benefit? In Paper presented at the annual meeting of the American Educational Research Association, San Francisco.

Morris-Rothschild, B. K., \& Brassard, M. R. (2006). Teachers' conflict management styles: The role of attachment styles and classroom management efficacy. Journal of School Psychology, 44(2), 105-121 https://doi.org/10.1016/j.jsp.2006.01.004.

Moustakas, C. (1994). Phenomenological research methods. Norwich: Jarrold and Sons, Ltd.

Mustafa, G., Glavee-Geo, R., Gronhaug, K., \& Almazrouei, H. (2019). Structural impacts on formation of self-efficacy and its performance effects. Sustainability, 11(1), 1-24 https://doi.org/10.3390/su11030860.

Pakarinen, E., Lerkkanen, M. K., Poikkeus, A. M., Kiuru, N., Siekkinen, M., Rasku-Puttonen, H., \& Nurmi, J. E. (2010). Validation of the classroom assessment scoring system in Finnish kindergartens. Early Education and Development, 21(1), 95-124 https://doi.org/10.1080/10409280902858764.

Rastegar, M., \& Memarpour, S. (2009). The relationship between emotional intelligence and self-efficacy among Iranian EFL teachers. System, 37(4), 700-707.

Reyes, M. R., Brackett, M. A., Rivers, S. E., White, M., \& Salovey, P. (2012). Classroom emotional climate, student engagement, and academic achievement. Journal of Educational Psychology, 104(4), 700-712 https://doi.org/10.1037/a0027268.

Ross, J. A. (1992). Teacher efficacy and the effect of coaching on student achievement. Canadian Journal of Education, 17(1), 51-65 https://doi.org/10.2307/1495395

Ross, J. A. (1994). Beliefs that make a difference: The origins and impacts of teacher efficacy. In Paper presented at the Annual Meeting of the Canadian Association for Curriculum Studies, June.

Ross, J. A. (1998). The antecedents and consequences of teacher efficacy. In J. Brophy (Ed.), Advances in research on teaching, (pp. 49-73). Greenwich: JAI.

Ross, J. A., \& Bruce, C. (2007). Professional development effects on teacher efficacy: Results of randomized field trial. The Journal of Educational Research, 101(1), 50-60. https://doi.org/10.3200/JOER.101.1.50-60.

Ross, J. A., Hogaboam-Gray, A., \& Hannay, L. (2001). Effects of teacher efficacy on computer skills and computer cognitions of Canadian students in grades K-3. The Elementary School Journal, 102(2), 141-156 https://doi.org/10.1086/499697.

Shen, Y. (2009). Relationships between self-efficacy, social support, and stress coping strategies in Chinese primary and secondary school teachers. Stress and Health, 25(2), 129-138 https://doi.org/10.1002/smi.1229.

Skaalvik, E. M., \& Skaalvik, E. (2011). Teacher job satisfaction and motivation to leave the teaching profession: Relations with school context, feeling of belonging, and emotional exhaustion. Teaching and Teacher Education, 27(6), 1029-1038. https://doi.org/10.1016/.tate.2011.04.001.

Skaalvik, E. M., \& Skaalvik, E. (2019). Teacher self-efficacy and collective teacher efficacy: Relations with perceived job resources and job demands, feeling of belonging, and teacher engagement. Creative Education, 10(07), 1400-1424. https://doi.org/ 10.4236/ce.2019.107104.

Skaalvik, E. M., \& Skaalvik, S. (2007). Dimensions of teacher self-efficacy and relations with strain factors, perceived collective teacher efficacy, and teacher burnout. Journal of Educational Psychology, 99(3), 611-625 https://doi.org/10.1037/00220663.99.3.611.

Skaalvik, E. M., \& Skaalvik, S. (2010). Teacher self-efficacy and teacher burnout: A study of relations. Teaching and Teacher Education, 26(4), 1059-1069 https://doi.org/10.1016/j.tate.2009.11.001.

Soodak, L. C., \& Podell, D. M. (1993). Teacher efficacy and student problems as factors in special education referral. Journal of Special Education, 27(1), 66-81 https://doi.org/10.1177/002246699302700105.

Soodak, L. C., \& Podell, D. M. (1996). Teacher efficacy: Toward the understanding of a multi-faceted construct. Teaching and Teacher Education, 12(4), 401-411 https://doi.org/10.1016/0742-051X(95)00047-N.

Strauss, A., \& Corbin, J. (1998). Basics of qualitative research. Thousand Oaks: Sage. 
Thoonen, E. E. J., Sleegers, P. J. C., Oort, F. J., Peetsma, T. T. D., \& Geijsel, F. P. (2011). How to improve teaching practices: The role of teacher motivation, organizational factors, and leadership practices. Educational Administration Quarterly, 47(3), 496-536 https://hdl.handle.net/11245/1.349085.

Tournaki, N., \& Podell, D. M. (2005). The impact of student characteristics and teacher efficacy on teachers' predictions of student success. Teaching and Teacher Education, 21(3), 299-314 https://doi.org/10.1016/j.tate.2005.01.003.

Tschannen-Moran, M., \& Hoy, A. W. (2001). Teacher efficacy: Capturing an elusive construct. Teaching and Teacher Education 17(7), 783-805 https://doi.org/10.1016/50742-051X(01)00036-1.

Tschannen-Moran, M., \& Hoy, A. W. (2007). The differential antecedents of self-efficacy beliefs of novice and experienced teachers. Teaching and Teacher Education, 23(6), 944-956 https://doi.org/10.1016/j.tate.2006.05.003.

Tschannen-Moran, M., Hoy, A. W., \& Hoy, W. K. (1998). Teacher efficacy: Its meaning and measure. Review of Educational Research, 68(2), 202-248 https://doi.org/10.3102/00346543068002202.

Tsitouridou, M., \& Vryzas, K. (2004). The prospect of integrating ICT into the education of young children: the views of Greek early childhood teachers. European Journal of Teacher Education, 27(1), 29-45.

Tzioti, et al. (2010). Job burnout and self-efficacy survey among elementary school teachers in Greece. Annals of General Psychiatry, 9(I), 192-198 https://doi.org/10.1186/1744-859X-9-S1-S192.

Tzur, K. S., Ganzach, Y., \& Pazy, A. (2016). On the positive and negative effects of self-efficacy on performance: Reward as a moderator, 29(5), 362-377 https://doi.org/10.1080/08959285.2016.1192631.

Woolfolk, A. (2004). Educational psychology, (9th ed., ). India: Pearson Education.

Woolfolk, A. E., \& Hoy, W. K. (1990). Prospective teachers' sense of efficacy and beliefs about control. Journal of Educational Psychology, 82(1), 81-91 https://doi.org/10.1037/0022-0663.82.1.81.

Wyatt, M. (2018). Language Teachers' Self-efficacy Beliefs: A Review of the Literature (2005-2016). Australian Journal of Teacher Education, 43(4) https://doi.org/10.14221/ajte.2018v43n4.6.

Yoon, J. S. (2004). Predicting teacher interventions in bullying situations. Education \& Treatment of Children, 27(1), 37-45.

\section{Publisher's Note}

Springer Nature remains neutral with regard to jurisdictional claims in published maps and institutional affiliations.

\section{Submit your manuscript to a SpringerOpen ${ }^{\circ}$ journal and benefit from:}

- Convenient online submission

- Rigorous peer review

- Open access: articles freely available online

High visibility within the field

- Retaining the copyright to your article

Submit your next manuscript at $\boldsymbol{s p r i n g e r o p e n . c o m ~}$ 